BIOKEMISTRI 18(2):71-76 (December 2006)

Available online at http://www.bioline.org.br/bk and at http://www.ajol.info/journals/biokem

Printed in Nigeria

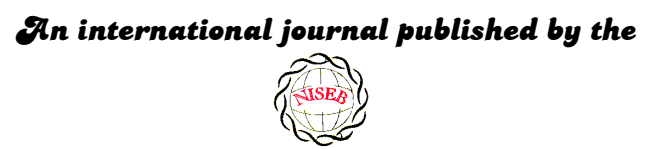

OVigerian Society for Ëxperimental \&Siology

\title{
Serum ferritin levels in children with malaria anaemia in Ibadan
}

\author{
Chiaka I. ANUMUDU*, Adebayo J. MOLEHIN, Saheed O. OLADITI and \\ Christian M. F. OKAFOR
}

Cellular Parasitology Programme, Department of Zoology, University of Ibadan, Ibadan, Nigeria

Received 16 January 2006

MS/No BKM/2006/001, (C2006 Nigerian Society for Experimental Biology. All rights reserved.

\begin{abstract}
This study assessed the serum ferritin levels in plasma samples from children (4 - 74 months old) admitted for malaria at the Adeoyo Maternity Hospital (Beere) Ibadan, Oyo State, using a sandwich-ELISA. These values were compared with malaria parasitemia, MSP-1 antibody titre and packed cell volume values previously obtained through standard methods. Statistical analyses were carried out using SPSS, Excel and Epi-Calc software. Results showed that the serum ferritin level in the population ranged in from $363 \mathrm{ng} / \mathrm{ml}$ to $1000 \mathrm{ng} / \mathrm{ml}$, with a mean value of $630 \mathrm{ng} / \mathrm{ml}$. There was a negative correlation between serum ferritin levels and the packed cell volume, and malaria parasitemia in the children; while the serum ferritin levels increased with increasing malaria antibodies. There was no significant difference in the mean levels of ferritin in anaemic and non-anaemic children. Serum ferritin concentration decreased with increasing age in children with malaria. Gender was found to have no significant association with serum ferritin levels in children with malaria anaemia.
\end{abstract}

Keywords: Ferritin levels, children, malaria, Ibadan

* E-mail: cianumudu@ yahoo.com, Tel: +234-2-7519227 


\section{INTRODUCTION}

Ferritin is an iron- containing spherical rhombic dodecahedron protein shell of 24 repeating subunits with a molecular weight of approximately $460 \mathrm{KDa}$ and an iron core of ferric-oxide phosphate. When fully saturated, it may be over $20 \%$ iron by weight ${ }^{1}$. Serum ferritin, an acute phase reactant, rises with any inflammatory process from infection, through chronic disease, like malaria ${ }^{2}$. Serum ferritin concentrations of less than $12 \mu \mathrm{g} / \mathrm{L}$ are highly predictive of iron deficiency, defined by the absence of iron stores ${ }^{3}$.

Alteration in serum ferritin levels are important not only in the classical diseases of iron acquisition, transport, and haemochromatosis, but also in diseases characterized by inflammation, infection, injury and repair e.g. malaria, worm infestation ${ }^{4}$. Anumudu et al. ${ }^{5}$ showed that the most common clinical manifestation of acute severe malaria in southwestern Nigeria is anaemia. Pathogenic mechanisms such as haemolysis, impaired erythropoiesis ${ }^{6}$, and possibly iron sequestration and iron deficiency ${ }^{7}$ could contribute to the anaemia, and serum ferritin levels have been shown to increase with increasing malaria density ${ }^{8,9}$.

Studies have shown that in holoendemic areas, children below 5 years of age are the most vulnerable to severe and complicated malaria, since their immunity to malaria is still very poor $^{10-12}$. Studies on serum ferritin levels in Nigeria were carried out on children older than 5 years of age and adults, ${ }^{9,13}$. In this study, we determined the serum ferritin levels in children below 5 years of age with malaria anaemia.

\section{MATERIALS AND METHODS}

\section{Study design}

Blood samples were collected from 228 children below 5 years of age with clinical suspicion of malaria and those admitted for severe malaria, with PCV less than $15 \%$ in the Adeoyo State Maternity Hospital, Ibadan. Blood smears were stained by Giemsa for parasite density, and plasma samples were analyzed by sandwich-
ELISA to measure the serum ferritin levels in all the subjects.

\section{Detection of ferritin levels by sandwich- ELISA}

A sandwich-ELISA in which the serum ferritin was trapped between two monoclonal antibodies developed in rabbits (Sigma MO, USA) was used to determine serum ferritin levels. Polystyrene plates were coated with $100 \mu \mathrm{l} /$ well anti-human ferritin monoclonal antibody (Mab) diluted 1:500 in carbonate buffer, and incubated overnight at $4^{\circ} \mathrm{C}$. Plates were washed three times with PBS/Tween 20 buffer and then blocked with $200 \mu \mathrm{l} /$ well of blocking buffer $(1 \%$ BSA/Tween20), incubated for one hour at $37^{\circ} \mathrm{C}$. Serum was added at 1:50 dilution in blocking buffer $(100 \mu \mathrm{l} / \mathrm{well})$ and incubated at $37^{\circ} \mathrm{C}$ for one hour and washed. Then, anti-human ferritin Monoclonal antibody (Mab) was added at 1:500 dilution in blocking buffer and incubated at $37^{\circ} \mathrm{C}$ for one hour. The excess was poured off and plate washed three times with PBS/Tween20. Goat anti rabbit antibody conjugated to horseradish peroxidase was added at 1:2000 dilution in blocking buffer $(100 \mu \mathrm{l} /$ well $)$ and incubated at $37^{\circ} \mathrm{C}$ for one hour. The excess was poured off and plate washed three times with PBS/Tween20. Finally, for colour development, peroxidase substrate; 2,2-Azino-Bis(3-ethylbenthiazoline)sulphate VI, (ABTS) and peroxidase substrate solution $\mathrm{B}$ in ratio $1: 1$, was added at $100 \mu 1 /$ well and incubated at $37^{\circ} \mathrm{C}$ for 30minutes. Plates were read at A405nm, with an ELISA microplate reader (Molecular devices, USA).

Antibody Response to MSP-1 19 An enzyme linked immunosorbent assay (ELISA) was used to determine the levels of antibodies to MSP-1 19 as earlier reported ${ }^{14}$. 96-well polystyrene microtitre plates (Dynatech USA) were coated with $50 \mu \mathrm{g} / \mathrm{ml}$ MSP- $1_{19}$ in $0.1 \mathrm{M}$ carbonate coating buffer, $\mathrm{pH} 9.6$ and incubated overnight at $4^{\circ} \mathrm{C}$. Plates were then washed 3 times with washing buffer $(0.05 \%$ Tween 20 in phosphate buffered saline). The wells of the plate were filled with blocking buffer (1\% PBS / $0.5 \%$ Tween $20 / 1 \%$ Bovine serum albumin, $\mathrm{pH}$ 
7.4) and incubated for 1 hour at $37^{\circ} \mathrm{C}$. Plasma samples were diluted serially $1: 50-1: 6400$ in blocking buffer $(50 \mu \mathrm{l} /$ well $)$ and incubated for 1 hour at $37^{\circ} \mathrm{C}$, after which plates were washed 3 times with washing buffer. Bound antibodies were subsequently detected with 1:2000 horseradish peroxidase conjugated to rabbit $\operatorname{lgG}$ (Kirkegaard and Perry Labs, USA) and the reaction developed with ABTS/hydrogen peroxide substrate solution. A microplate absorbance reader (Molecular Devices, USA) was used to read the plates at optical density of $650 \mathrm{~nm}$. The end point titre was the highest serum dilution that had an absorbance value above that of the negative control at 1:50 dilution. The $\mathrm{MSP}_{19}$ antibody titre was expressed as the log reciprocal of the serum dilution.

\section{PCV determination}

Haemoglobin estimation was done by the cyanomethemoglobin method $^{15}$. The PCV was determined by spinning the samples in capillary tubes at $12,000 \mathrm{~g}$ for 10 minutes. PCV values were then read off the microhaematocrit reader. The samples were analyzed in duplicate and the mean values recorded.

\section{Statistical Analyses}

The data were entered with Excel software. Correlation analyses between serum ferritin values and age, sex, PCV, anti-MSP1 antibodies and parasitaemia were carried out using the SPSS, EPI- calc and Excel Packages. ANOVA was also used to estimate the correlation between the children age groups and serum ferritin level.

\section{RESULTS}

A total of 228 serum samples from children between the ages of 4-74 months were analyzed. The serum ferritin levels were quantified with a sandwich ELISA developed in the laboratory and a ferritin standard curve. The optical density (OD) value of the serum ferritin level in the population ranged from 0.65 to 2.22 , with a mean of 1.33 . About $40 \%(91 / 228)$ of the serum samples analyzed with ELISA had their OD values (0.65-1.20) extrapolated into $\mathrm{ng} / \mathrm{ml}$ from the ferritin standard curve available. The serum ferritin values ranged from $363 \mathrm{ng} / \mathrm{ml}$ to
$1000 \mathrm{ng} / \mathrm{ml}$ (mean, 630ng/ml). The anaemic $(\mathrm{PCV} \leq 25 \%)$ and non-anaemic $(\mathrm{PCV}>25 \%)$ patients had serum ferritin concentration ranged from 363 to $1000 \mathrm{ng} / \mathrm{ml}$ and 363 to $530 \mathrm{ng} / \mathrm{ml}$ respectively.

Parasite density ranged between 80-100,000 parasites/ $\mu$ l blood. Packed Cell Volume (PCV) values ranged from 8 to $45 \%$ in the sample population. The results showed that the serum ferritin concentration increased with decreasing packed cell volume, $r=-0.2$ (Figure 1) and there was no statistically significant difference between the mean serum ferritin concentrations in anaemic and non-anaemic subjects $(\mathrm{p}=0.57)$.

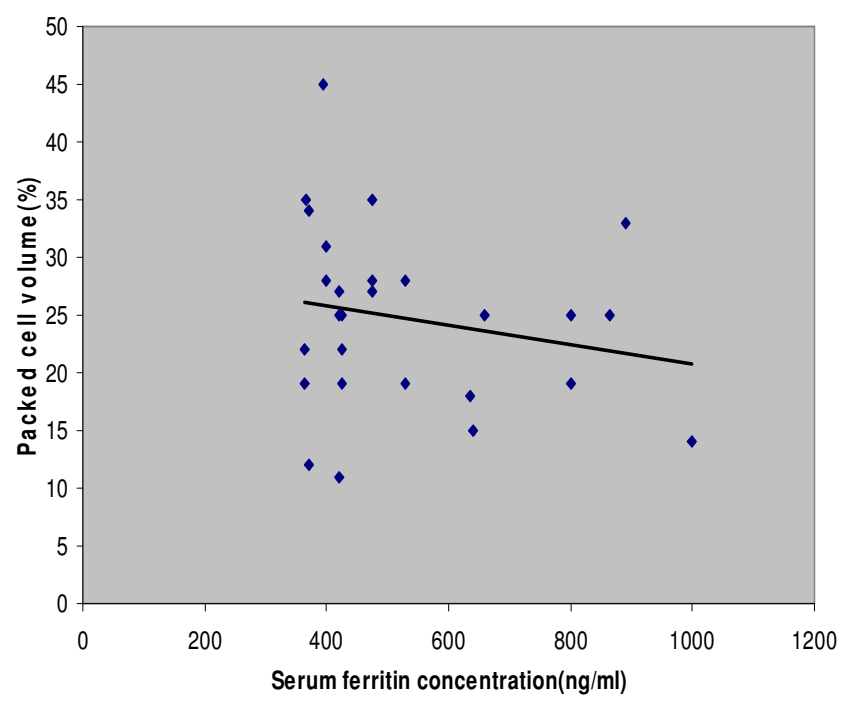

Figure 1: Correlation between serum ferritin concentration $(\mathrm{ng} / \mathrm{ml})$ and packed cell volume $(\mathrm{r}=$ -0.20). Serum ferritin concentration ( $\mathrm{gg} / \mathrm{ml})$ increases with decreasing packed cell volume

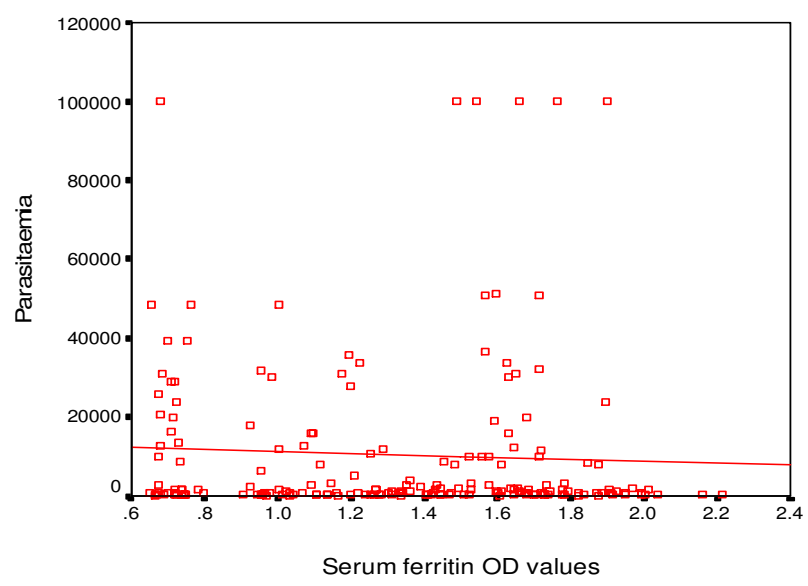

Figure 2: Correlation between serum ferritin and parasitaemia in children 
There was a negative correlation between the parasite density and serum ferritin levels, $r=$ -0.53 (Figure 2). Serum ferritin levels decreased with increasing parasitaemia in the children.

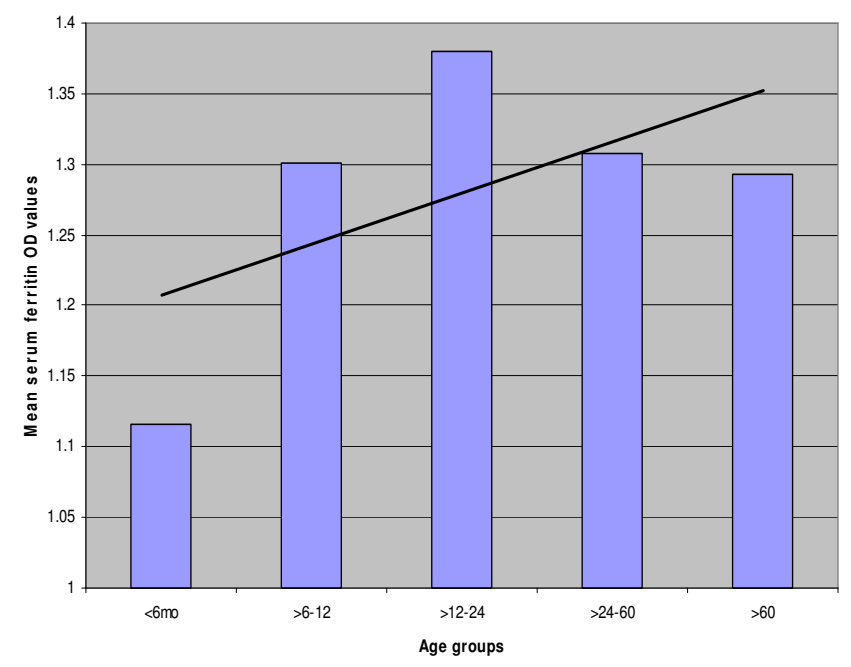

Figure 3: Serum ferritin levels are highest in children 12-24 months old.

There was an increase in the serum ferritin levels in children aged less than 24 months and a decrease in children older than 24 months (Figure 3). Gender had no influence on the levels of serum ferritin in children with malaria anaemia $(\mathrm{p}=0.13)$.

\section{DISCUSSION}

Anaemia did not alter the serum ferritin levels in the children as there was no statistically significant difference between the mean serum ferritin concentrations of the anaemic and the non-anaemic children, which is in contrast with the work of Stoltzfus et $a l^{16}$ and Phillips et al. ${ }^{17}$ They found that the destruction of red blood cells during malaria and suppression of erythropoiesis resulting in profound anaemia, would shift iron out of heme towards storage form; and as long as heme is effectively recycled, the total body stores of iron would not be altered, although iron status indicators like serum ferritin will certainly be altered. It was also in contrast a study ${ }^{18}$ which found higher plasma ferritin concentrations in anaemia patients than in the control children.
The serum ferritin levels in the children decreased with increasing parasitemia. We do not know the precise mechanism for this result. However several studies reported an increased serum transferrin receptor concentration and decreased serum ferritin in persons with symptomatic and mildly symptomatic falciparum malaria ${ }^{8,19,20,21}$. Also, acute erythropoietin deficiency ${ }^{22}$ or suppression of marrow response to erythropoietin could lead to decreased erythropoiesis and thus low serum ferritin concentrations.

The observed high mean serum ferritin in age groups of less than 24 months and decline in levels in the age group older than 24 months could be explained by the fact that iron stores are known to rapidly decline during and after infancy, as a result of growth and associated haemodilution $^{23}$. This is consistent with a study ${ }^{8}$ in which children less than 30 months old had increased serum ferritin with increasing malaria density, while in children older than 30 months old, serum ferritin was not associated with malaria parasite density. In a study with adults in Lagos ${ }^{13}$, it was found that all haematological parameters measured were similar in both elderly males and females, except ferritin, haematocrit and haemoglobin, which were significantly higher in males. In our study, we could ascribe no differences in serum ferritin levels to gender.

\section{REFERENCES}

1. Worwood, M. (2005) Soluble transferrin receptor and iron homeostasis. Haematologica 90: 2.

2. Herbert, V., Jayatilleke E., Shaw S., Rosman A.S., Giardina P., Grady R.W., Bowman B. and Gunter EW (1997) Serum ferritin iron, a new test, measures human body iron-stores unconfounded by inflammation. Stem Cells 15: 291-296

3. Cook, J. D. (1994) Iron deficiency anaemia. Clin Haematol 7: 784-804

4. Torti, F. M., and Torti, S.V., (2002) Regulation of ferritin genes and protein. Blood 99: 3505-3516 
5. Anumudu, C. I., Okafor, C. M. F., Ngwumahaike, V., Afolabi, K. A., Nwuba, R. I. and Nwagwu, $M$. (2004) Clinical manifestation and immune response to MSP-19 in severe paediatric malaria in Adeoyo state maternity hospital, Ibadan. Afr. J. Med. Sci. 33:57-63

6. Abdalla, S. H. (1990) Hematopoiesis in human malaria. Blood cells 16:401-16.

7. Brabin, B. J. (1992) The role of malaria in nutritional anemia. In: Fomon SJ, Slotkins $S$ (eds). Nutritional Anemia. New York. Raven press p65-80

8. Stoltzfus, R. J., Chwaya, H. M., Montresor A, M., Albonico, M., Savioli, L. and Tielsch, J. M. (2000) Malaria, hookworms and recent fever are related to anaemia and iron status indicators in 0 - to $5 \mathrm{yr}$ old Zanzibari children and these relationships change with age. J. Nutr. 130: $1724-1733$

9. Odunukwe, N. N., Salako, L. A., Okanny, C., Ahmed, O. A., Mafe, A. G., Efinemokwu, C. and Raheem, T. Y. (2001) Serum ferritin and other haematological measurements in apparently healthy children with malaria parasitaemia in Lagos, Nigeria. West Afr. J. Med. 20:42-45.

10. World Health Organization. (1990) Severe and complicated malaria. Trans. Roy. Soc. Trop. Med. Hyg. 84: Suppl. II. 65pp

11. Hendrickse, R. G. (1991) Parasitic Diseases, In: Hendrickse R. G., Barr, D. B. G. Mathew, T.S. eds. Paediatrics in the Tropics. Blackwell Scienitific Publications p 697-710.

12. Chongsuphajaisiddh, T. (1991) Malaria. In: Stanfield P., Breuton M., Chan M., and Waterson T., eds. Disease of children in the subtropics and Tropics. Edward Arnolds p 647-674.

13. Odunukwe, N. N., Imonugo, I. O., Akanmu, A. S., Nnodu, O. E., Okanny, C. C., Akinsete I., Ahmed O. A. and Efienemokwu, C. (2004) Ferritin and haematological values in healthy elderly Nigerians. Turk J. Haematol. 21: 71-77.
14. Nwuba, R. I., Sodeinde, O., Anumudu, C. I., Omosun, Y. O., Odaibo, A. B., Holder, A. A. and Nwagwu, M. (2002) The human immune response to $P$. falciparum includes both antibodies that inhibit Merozoite surface protein 1 secondary processing and blocking antibodies. Infect. Immun. 70: 5328-5331.

15. Cartwright, G. E. (1968) Diagnostic laboratory haematology. Grunne and Stratton. New York.

16. Stoltzfus, R. J., Chwaya, H. M., Albonico, M., Schulze, K. J., Savioli, L. and Tielsch, J. M. (1997) Serum ferritin, erythrocyte protoporphyrin and hemoglobin are valid indicators of iron status of school children in a malariaholoendemic population. J. Nutr 127: 293 $-298$.

17. Phillips, R. E., Looareesuwan, S., Warrell, D. A., Lee, S. H., Karbwang, J., Warell, M. J., White, N. J., Sirasdichai, C. and Weatherall, D. J. (1986) The importance of anaemia in cerebral and uncomplicated falciparum malaria: role of complications, dyserythropoiesis and iron sequestration. Q. J. Med. 58:305-323

18. Adelekan, D. A. and Thurnham, D. I. (1990) Plasma ferritin concentrations in anaemic children and relative importance of malaria, riboflavin deficiency, and other infections. Am. J. Clin. Nutr. 51: 453-456.

19. Mockenhaupt, F. P., May, J., Stark, K., Falusi, A. G., Meyer, C. G. and Bienzle, U. (1999) Serum transferrin receptor levels are increased in asymptomatic and mild Plasmodium falciparum infection. Haematologica 84: 869-873.

20. Williams, T.N., Maitland, K., Rees D.C., Peto, T.E., Bowden, D.K., Weatherall, D.J. and Clegg, J.B. (1999) Reduced soluble transferrin receptor concentrations in acute malaria in Vanuatu. Am. J. Trop. Med. Hyg. 60:875-878

21. Beesley, R., Filteau, S. and Tomkins, A. (2000) Impact of acute malaria on plasma concentrations of transferrin receptors. Trans. R. Soc. Trop. Med. Hyg. 94:295-298. 
22. Burgmann, H., Looaresuwan, S. and Kapiotis, S. (1996) Serum levels of erythropoietin in acute Plasmodium falciparum malaria. Am J Trop Med Hyg 54: 280-283
23. Yip, R. (1994) Changes in iron metabolism with age. In: Brock JH, Halliday J, Pippard MJ, Powell LW (eds). Iron Metabolism in health and disease. WB Saunders. London p427-428 